\title{
Black shale Mo isotope record reveals dynamic ocean redox during the Mesoproterozoic Era
}

\author{
Y. Ye ${ }^{1,2}$, S. Zhang ${ }^{2 *}$, H. Wang ${ }^{2}$, X. Wang ${ }^{2}$, C. Tan ${ }^{2}$, M. Li ${ }^{3}$, \\ C. $\mathrm{Wu}^{1}$, D.E. Canfield ${ }^{2,4}$
}

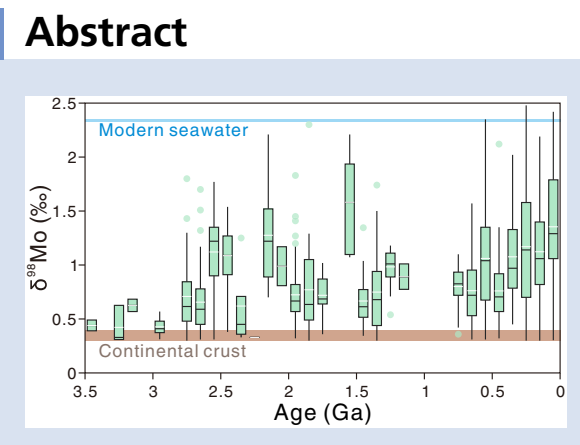

Received 17 January 2021 | Accepted 27 April 2021 | Published 15 June 2021

\section{Introduction}

The Mesoproterozoic Era has been described as a time of climatic, geochemical, and biological stasis. The relatively small carbonate carbon isotope variations and the absence of continental ice sheets contrast starkly with the following Neoproterozoic Era when low latitude glaciations and huge carbon isotope excursions were prevalent. Neoproterozoic marine environments also witnessed the diversification of eukaryotic phytoplankton and animals, which have long been linked to the surface oxygenation, while low oxygen availability in Mesoproterozoic oceans may have limited eukaryotic diversity and organismal complexity, generating a sluggish biosphere (Anbar and Knoll, 2002). This traditional view, however, is evolving with a growing amount of newly reported Mesoproterozoic fossils, such as the filamentous and lobate fossils, interpreted as probable crown group red algae, in the 1600 Ma Tirohan Dolomite of central India (Bengtson et al., 2017) and the 1560 Ma Gaoyuzhuang carbonaceous compressions closely resembling modern benthic algae (Zhu et al., 2016).

If we accept the notion that life has evolved with the environment, then these biological innovations should be considered together with the redox changes in Mesoproterozoic oceans. Indeed, existing data show that Mesoproterozoic deep waters had variable redox chemistry ranging between oxic, euxinic (sulfidic), and ferruginous conditions (Wang et al., 2017). Within the context of deep ocean redox fluctuations, there is a broad debate on atmospheric oxygen levels. Some studies have advocated very low concentrations of $0.1-1 \%$ PAL (present atmospheric level;
Planavsky et al., 2020), yet others provided evidence for minimum values of 1-4 \% PAL (Zhang et al., 2016; Canfield et al., 2018).

To develop and test these ideas, we present total organic carbon (TOC), Fe speciation, Mo abundance and isotopic compositions (denoted as $\delta^{98} \mathrm{Mo}_{\mathrm{NIST} 3134=0.25}$; Nägler et al., 2014) of shale samples from Mesoproterozoic strata spanning from $\sim 1560$ to $1170 \mathrm{Ma}$. Our results, combined with published data, comprise the most comprehensive current Mo isotope record of Mesoproterozoic marine settings and a valuable window into state of ocean redox.

\section{Geological Background and Samples}

Samples were obtained from two drill cores in the Yanliao Basin, North China (the Gaoyuzhuang and Hongshuizhuang Formations) and from multiple outcrops of the Shennongia Group, South China (Fig. 1). The Gaoyuzhuang Formation is composed of predominately carbonate rocks, and it can be divided into four lithological members (Shang et al., 2019). Our study focuses on Member III, where organic-rich calcareous shales were deposited in a relatively deep water environment. Based on zircon U-Pb ages, the time frame of Member III is constrained to $1580-1560 \mathrm{Ma}$ (Tian et al., 2015). Above the Gaoyuzhuang Formation, thick bedded dolostones of the Yangzhuang and Wumishan Formations make up the majority of the Jixian Group in North China. Subsequent transgression promoted the offshore deposition of the Hongshuizhuang

\footnotetext{
1. Key Laboratory of Orogenic Belts and Crustal Evolution, Ministry of Education, School of Earth and Space Sciences, Peking University, Beijing 100871, China

2. Key Laboratory of Petroleum Geochemistry, Research Institute of Petroleum Exploration and Development, China National Petroleum Corporation, Beijing 100083, China

3. School of Geophysics and Information Technology, China University of Geosciences, Beijing 100083, China

Department of Biology and Nordcee, University of Southern Denmark, Odense M 5230, Denmark

Corresponding author (email: sczhang@petrochina.com.cn)
} 


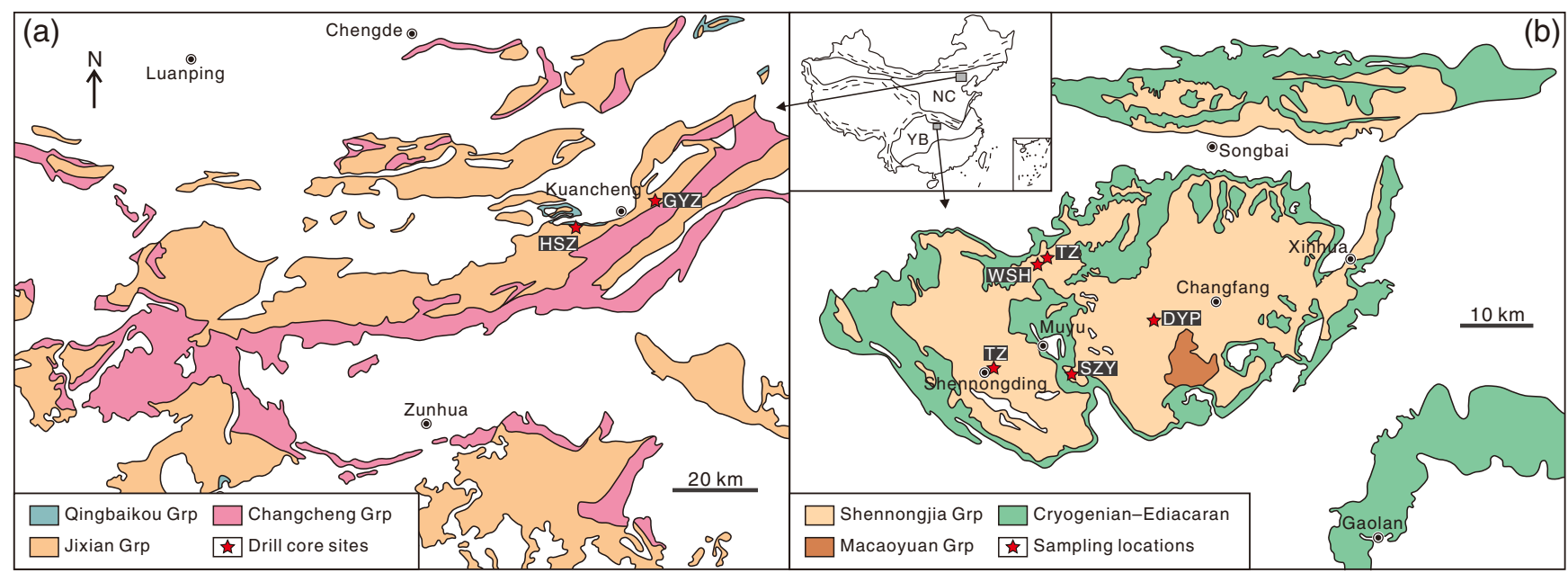

Figure 1 Maps showing the Proterozoic outcrops in the (a) Yanliao and (b) Shennongjia regions. Sampling locations are marked as stars. Formations: GYZ, Gaoyuzhuang; HSZ, Hongshuizhuang; DYP, Dayanping; TZ, Taizi; WSH, Wenshuihe; SZY, Songziyuan.

shales. No radiometric dating has been conducted for the Hongshuizhuang Formation itself, but U-Pb ages of $\sim 1480$ and 1440 Ma were reported from the underlying Wumishan Formation and the overlying Tieling Formation, respectively (Li et al., 2014).

The Shennongiia Group in the northern margin of the Yangtze Block has been explored geochemically for TOC, trace metals, and Cr isotopes (Canfield et al., 2018). Our samples for Mo isotope analysis were collected from the Dayangping, Taizi, Wenshuihe, and Songziyuan Formations. Organic-rich sediments of the latter three formations are enriched in redox sensitive elements, similar to other Mesoproterozoic black shales (Canfield et al., 2018). The base of the Shennongjia Group is estimated at $1400 \mathrm{Ma}$, while the uppermost layers deposited after 1100 Ma (see Canfield et al., 2018, for detailed stratigraphic and chronological descriptions).

\section{Results}

Our geochemical data are illustrated in Figure 2 (see Supplementary Information for methods). Ratios of $\mathrm{Fe}_{\mathrm{HR}} / \mathrm{Fe}_{\mathrm{T}}$ are relatively high (>0.38) in the Gaoyuzhuang and Hongshuizhuang Formations, but vary markedly through shales of the Shennongjia Group. Note that the Shennongiia samples are plotted sequentially by number and relative to stratigraphic position, instead of exact depth, thus the $\mathrm{Fe}_{\mathrm{HR}} / \mathrm{Fe}_{\mathrm{T}}$ variation does not necessarily reflect secular change. For samples with $\mathrm{Fe}_{\mathrm{HR}} / \mathrm{Fe}_{\mathrm{T}}>$ 0.38 , their $\mathrm{Fe}_{\mathrm{py}} / \mathrm{Fe}_{\mathrm{HR}}$ ratios are generally $<0.7$, while instances of elevated $\mathrm{Fe}_{\mathrm{py}} / \mathrm{Fe}_{\mathrm{HR}}(>0.7)$ exist in the Hongshuizhuang and Taizi Formations. Molybdenum isotope values range from $-1.07 \%$ o to $+2.21 \%$ o for the Gaoyuzhuang Formation, from $-0.64 \%$ to $+1.35 \%$ for the Hongshuizhuang Formation, and from -0.52 $\%$ o to $+1.12 \%$ o for the Shennongjia Group. The heaviest measured $\delta^{98} \mathrm{Mo}$ in the Gaoyuzhuang sediments coincides with enriched TOC and Mo contents, as well as a positive swing of the $\mathrm{Fe}_{\mathrm{py}} / \mathrm{Fe}_{\mathrm{HR}}$ profile.

\section{Molybdenum Isotopes as a Palaeoredox Proxy}

Molybdenum isotopes are a well established proxy used to reconstruct marine redox state. In modern oxygenated oceans, the isotopically heavy seawater Mo signal ( 2.34 \%o) mainly results from Mo uptake onto Mn oxide particles that preferentially adsorb light $\mathrm{Mo}$ isotopes $\left(\Delta^{98} \mathrm{Mo}_{\mathrm{SW}-\mathrm{Mn}-\mathrm{ox}}=\sim 3 \%\right.$; Siebert et al., 2003; Barling and Anbar, 2004). By contrast, in euxinic basins (often hydrographically restricted today), especially when $\left[\mathrm{H}_{2} \mathrm{~S}\right]_{\mathrm{aq}}$ exceeds $11 \mu \mathrm{M}$ (Erickson and Helz, 2000), $\mathrm{Mo}$ is efficiently removed from solution into sediments. Molybdenum isotopes of these sediments can reach isotopically heavy values close to open ocean seawater values (Neubert et al., 2008). Such a near quantitative Mo transfer allows the use of euxinic deposits to infer seawater Mo isotope compositions. For sediments bathed under anoxic but non-euxinic or low $\left[\mathrm{H}_{2} \mathrm{~S}\right]_{\mathrm{aq}}$-containing waters, a wide range of $\delta^{98} \mathrm{Mo}$ is observed (with a preferential retention of light mass Mo isotopes in sediments), likely reflecting the non-quantitative trapping of dissolved Mo and complexation of Mo with metal oxides or organic matter (Kendall et al., 2017).

The proportion of $\mathrm{Fe}$ among its geochemically reactive phases can be indicative of the redox chemistry directly above the accumulating sediments. The majority of our samples possess $\mathrm{Fe}_{\mathrm{HR}} / \mathrm{Fe}_{\mathrm{T}}>0.38$ but $\mathrm{Fe}_{\mathrm{py}} / \mathrm{Fe}_{\mathrm{HR}}<0.7$ or slightly $>0.7$, defining deposition under ferruginous to intermittently euxinic environments (Fig. 2; Poulton and Canfield, 2011). Since $\left[\mathrm{H}_{2} \mathrm{~S}\right]_{\text {aq }}$ strongly affects the removal of Mo, it is likely that low $\left[\mathrm{H}_{2} \mathrm{~S}\right]_{\text {aq }}$ would have imparted an isotope fractionation during Mo burial. Accordingly, our measured $\delta^{98} \mathrm{Mo}$ values may provide a minimum constraint on coeval seawater composition. In addition, the low $\mathrm{Fe}_{\mathrm{ox}} / \mathrm{Fe}_{\mathrm{HR}}$ ratios of core materials and finely distributed pyrites under scanning electron microscope suggest a minor influence of post-depositional alternation (Supplementary Information).

\section{Mesoproterozoic Molybdenum Record from Black Shales}

In order to investigate the evolution of marine oxygenation, we compare our results with published $\delta^{98} \mathrm{Mo}$ data over geological time (Fig. 3). Our compilation reveals broad changes in global ocean redox during the Mesoproterozoic Era. Moderate $\delta^{98} \mathrm{Mo}$ values $(<1.35 \%$ ), including samples from the Hongshuizhuang Formation and Shennongjia Group, dominate the Mesoproterozoic shale record, but excursions to higher $\delta^{98} \mathrm{Mo}$ values are observed in the Gaoyuzhuang $\left(\delta^{98} \mathrm{Mo}_{\max }=2.21 \%\right.$ o 
(a)

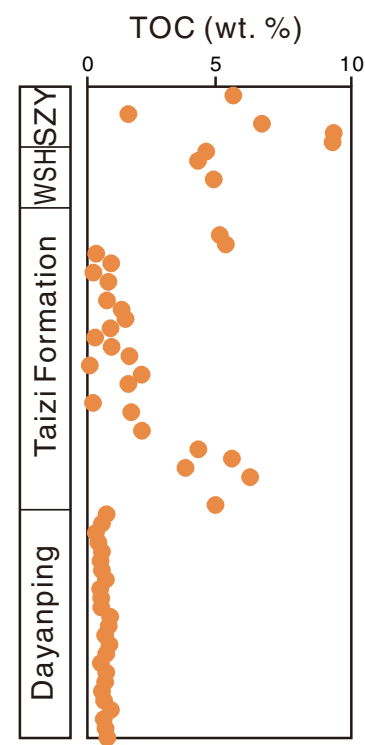

$\mathrm{Fe}_{\mathrm{HR}} / \mathrm{Fe}_{\mathrm{T}}$

$\mathrm{Fe}_{\mathrm{py}} / \mathrm{Fe}_{\mathrm{HR}}$

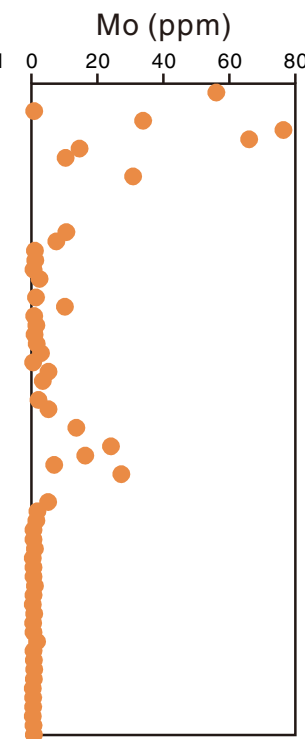

$\delta^{98} \mathrm{Mo}(\% \circ)$
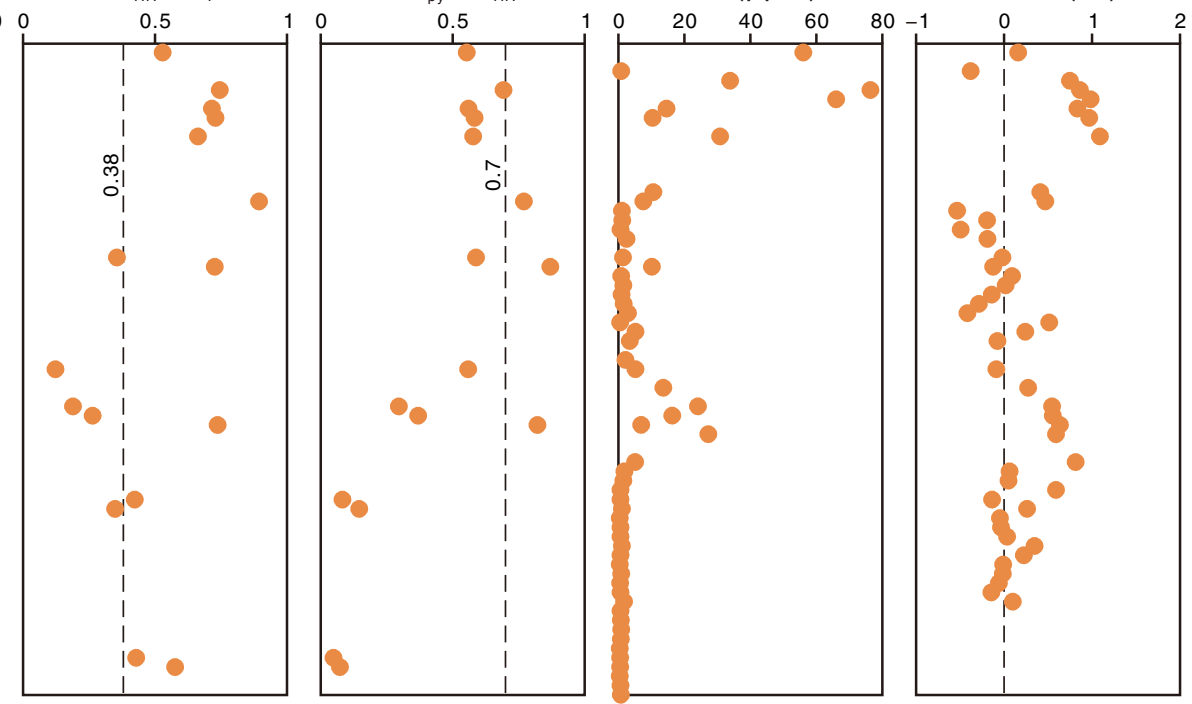

(b)
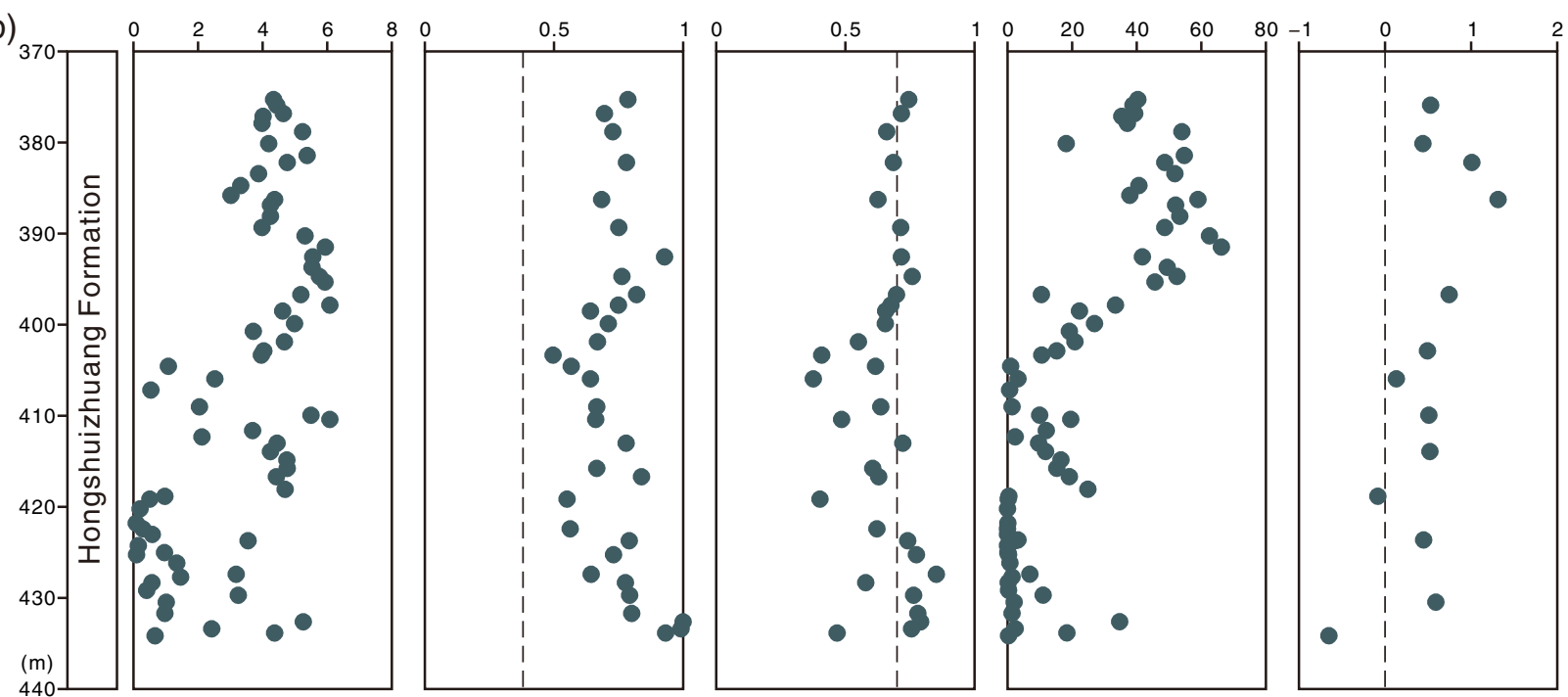

(c)
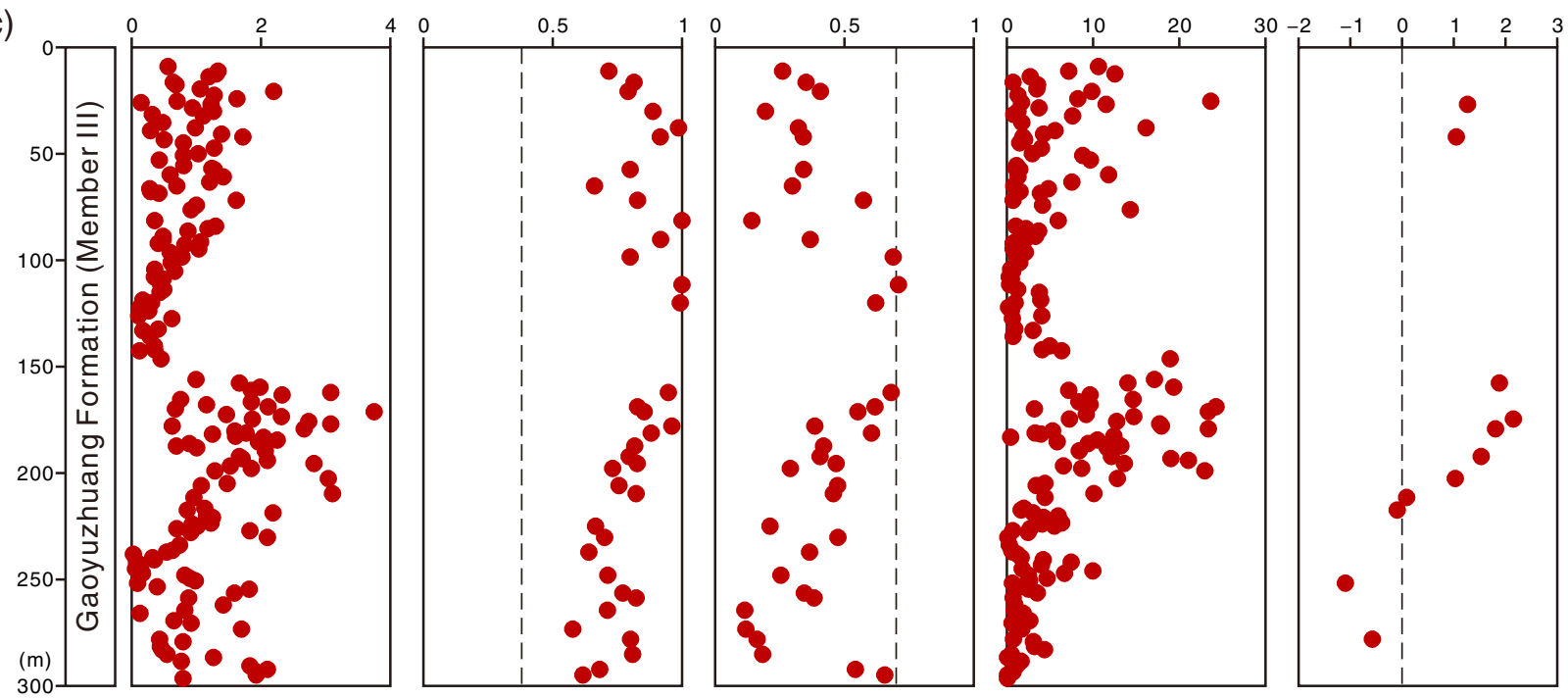

Figure 2 Geochemical profiles for shales from the (a) Shennongjia Group, (b) Hongshuizhuang Formation, and (c) Gaoyuzhuang Formation (Member III). The TOC and Mo contents of the Shennongjia Group are compiled from Canfield et al. (2018). Note that the Shennongjia samples are plotted sequentially and relative to stratigraphic position, but not as a function of depth. 

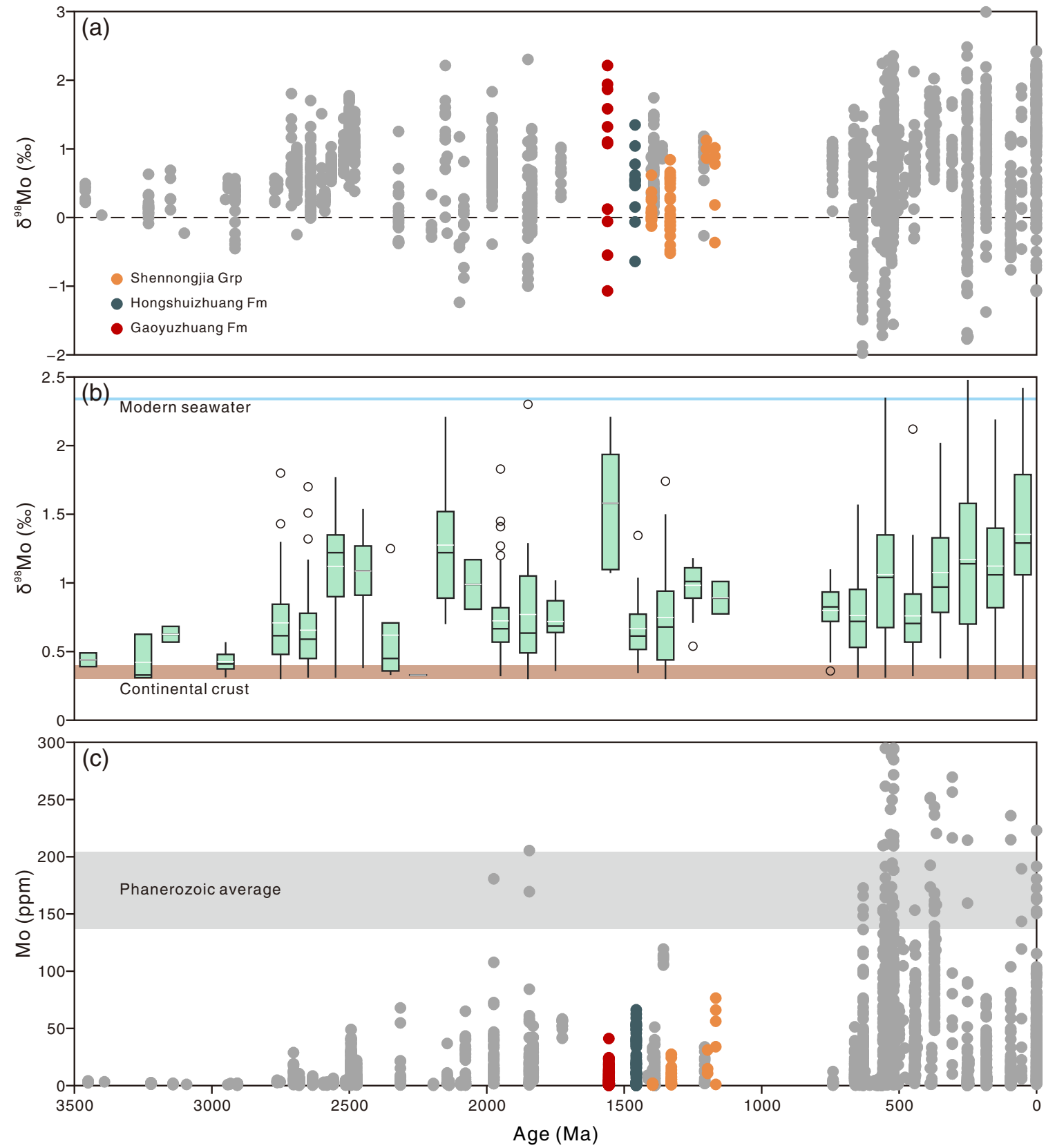

Figure 3 Black shale Mo record. (a) Mo isotope ratios from the Palaeoarchean to present. (b) Filtered data in 100 million year bins, focusing on samples with $\delta^{98}$ Mo greater than the continental crust composition $(>0.3 \%)$. The Box and Whisker plots show the first quartile, mean (white lines), median (black lines), third quartile, and outliers of the data. (c) Mo concentrations through time.

and Xiamaling Formations ( $1400 \mathrm{Ma}, \delta^{98} \mathrm{Mo}_{\max }=1.74 \%$; Diamond et al., 2018). On the basis of Mo isotope systematics, such heavy $\delta^{98}$ Mo values would require substantial sinks for isotopically light Mo on the seafloor. Does this mean that the ocean was at least temporarily well oxygenated during the Mesoproterozoic? We argue that these data should be interpreted cautiously and with considerations of the contemporaneous marine Mo inventory. It is expected that a well oxygenated ocean would be characterised by heavy seawater $\delta^{98}$ Mo and a large dissolved Mo reservoir (and correspondingly enhanced Mo enrichments in the few anoxic regions). We note, however, that in the Gaoyuzhuang Formation highly elevated $\delta^{98} \mathrm{Mo}$ values occur at Mo concentrations that are much lower than Phanerozoic equivalents (Fig. 3).

The low Mo concentrations may be partly attributed to the calcareous and ferruginous nature of our Gaoyuzhuang samples.
Alternatively, the elevated $\delta^{98} \mathrm{Mo}$ values need not have been associated with the same extent of seafloor oxygenation as today. That is to say, if some intermediate redox sinks could scavenge isotopically light Mo, but with relatively high burial efficiency, elevated $\delta^{98} \mathrm{Mo}$ values could have accompanied sedimentary Mo concentrations lower than those found in the Phanerozoic (Asael et al., 2018). In the following section, we explore this scenario mathematically through the ocean Mo mass balance model.

\section{Model for Marine Redox Distribution}

At steady state, the marine Mo input flux is balanced by removal into oxic, strongly euxinic, and intermediate (mildly reducing, including oxygen minimum zones, ferruginous waters, and other 


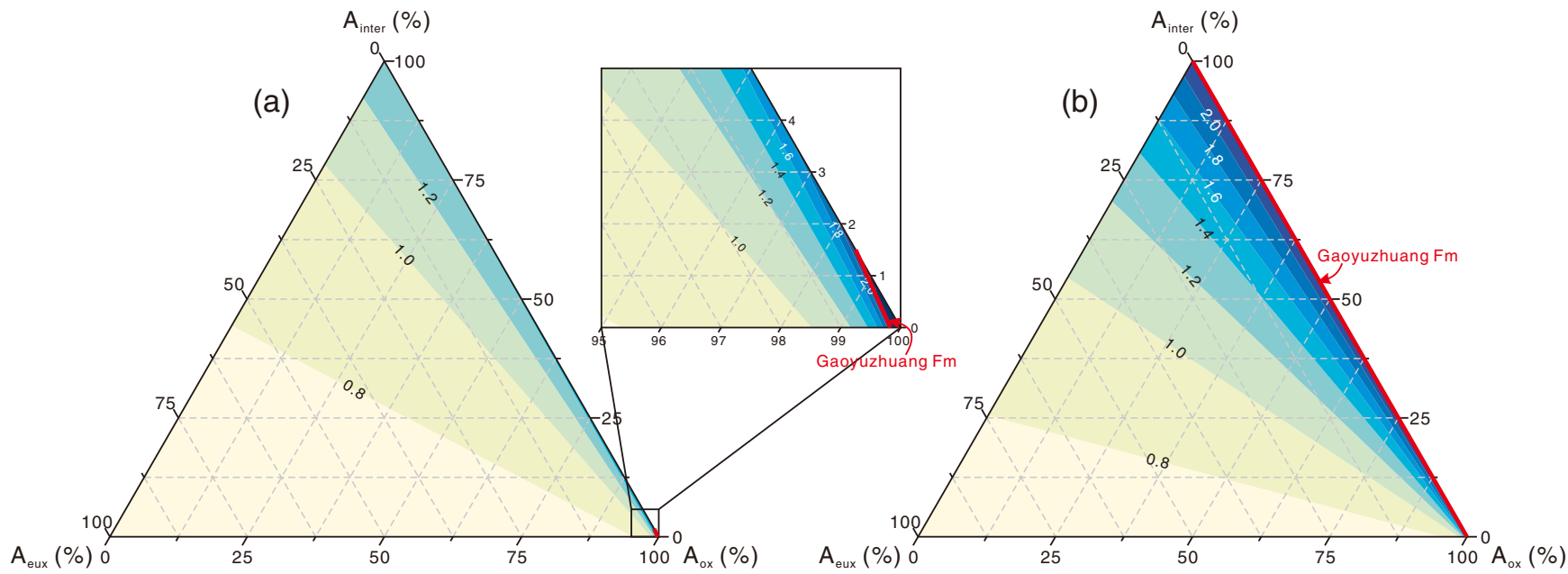

Figure 4 Estimates of ocean redox through the Mo isotope mass balance model, where $A_{o x}, A_{\text {inter, }}$ and $A_{\text {eux }}$ denote the seafloor areas of oxic, intermediate reducing, and strongly euxinic conditions, respectively. The left panel (a) is based on a fractionation of $0.7 \%$ for the intermediate sink, while the right panel (b) employs a larger fractionation of $1.5 \%$ for this sink.

low oxygen or intermittently euxinic settings) sinks. Of all the fractionations involved, those related to the intermediate sink are the least well constrained, yet an empirical fractionation of $0.7 \%$ is commonly chosen for this sink (Kendall et al., 2017). With this isotope offset, a seawater $\delta^{98} \mathrm{Mo}$ of $2.21 \%$, as we suggest for Member III of the Gaoyuzhuang Formation, can only be achieved with modern-like ocean oxygenation (or nearly so; Fig. 4). However, the magnitude of Mo isotope fractionation under the intermediate contexts can span the entire range between oxic and strongly euxinic end members. For example, as recently shown, ferruginous conditions can imprint greater isotope fractionation between sediments and the overlying bottom waters $\left(\Delta^{98} \mathrm{Mo}_{\mathrm{BW}-\mathrm{sed}}=0.6-2 \%\right.$; Hutchings et al., 2020). If we adjust a relatively larger factor $(1.5 \%)$ for the intermediate sink, the heavy $\delta^{98}$ Mo of the Gaoyuzhuang Formation can be reconciled with a line almost overlapping the $A_{o x}-A_{\text {inter }}$ axis, which indicates either substantial oxygenated or mildly reducing water masses (Fig. 4). In the intermediate redox environments, Mo might be efficiently scavenged by organic matter, Fe oxides, or FeS colloids (Swanner et al., 2020), thus in agreement with low seawater Mo concentrations as noted above.

\section{Implications of Dynamic Ocean Redox}

A growing body of ecological and geochemical evidence hints at a dynamic and patchy redox landscape for the Mesoproterozoic oceans (Zhang et al., 2018; Shang et al., 2019). The Mo isotope results presented here are consistent with this idea, with decided intervals indicating expanded oxygenated and/or mildly reducing waters relative to a baseline of more strongly euxinic conditions. Moreover, bootstrap resampled means of $\delta^{98} \mathrm{Mo}$ from the Mesoproterozoic exhibit greater dispersion compared with the Phanerozoic (Supplementary Information). The recognition of redox oscillations raises critical questions about possible relationships to biological innovation. In fact, the heavy $\delta^{98} \mathrm{Mo}$ values of the Gaoyuzhuang Formation are concurrent with body fossil evidence for macroscopic multicellular eukaryotes that lived near the storm wave base (Zhu et al., 2016). If such $\delta^{98}$ Mo signatures were associated with ocean oxygenation and increasing atmospheric oxygen levels, then multicellular eukaryotes may have evolved and expanded into a permissive chemical context. Whether subsequent expansions of marine anoxic conditions have provided a hindrance to further eukaryotic evolution depends on the baseline oxygenation of the Mesoproterozoic oceans, an issue that is still unresolved. Nevertheless, future analyses of larger sample sets promise new insights into the interaction between ocean redox and bio-diversification during the Mesoproterozoic Era.

\section{Acknowledgments}

We thank Hanjie Wen for assistance with Mo isotope analyses and Gavin Foster for editorial handling. This work was funded by the National Key Research and Development Program of China (2017YFC0603101), the National Science and Technology Major Project of the Ministry of Science and Technology of China (2016ZX05004001), the Strategic Priority Research Program of the Chinese Academy of Sciences (XDA14010101), the National Natural Science Foundation of China (41530317, 41872125), and the Villum Foundation (16518). Constructive comments from Noah Planavsky and two anonymous reviewers greatly improved the manuscript.

Editor: Gavin Foster

\section{Additional Information}

Supplementary Information accompanies this letter at https:// www.geochemicalperspectivesletters.org/article2118.

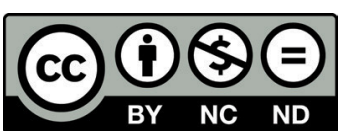

(C) 2021 The Authors. This work is distributed under the Creative Commons Attribution NonCommercial No-Derivatives 4.0 License, which permits unrestricted distribution provided the original author and source are credited. The material may not be adapted (remixed, transformed or built upon) or used for commercial purposes without written permission from the author. Additional information is available at https://www. geochemicalperspectivesletters.org/copyright-and-permissions.

Cite this letter as: Ye, Y., Zhang, S., Wang, H., Wang, X., Tan, C., Li, M., Wu, C., Canfield, D.E. (2021) Black shale Mo isotope record reveals dynamic ocean redox during the Mesoproterozoic Era. Geochem. Persp. Let. 18, 16-21. 


\section{References}

Anbar, A.D., Knoll, A.H. (2002) Proterozoic ocean chemistry and evolution A bioinorganic bridge? Science 297, 1137-1142.

Asael, D., Rouxel, O., Poulton, S.W., Lyons, T.W., BeKKer, A. (2018) Molybdenum record from black shales indicates oscillating atmospheric oxygen levels in the early paleoproterozoic. American Journal of Science 318, 275-299.

BARLING, J., ANBAR, A.D. (2004) Molybdenum isotope fractionation during adsorption by manganese oxides. Earth and Planetary Science Letters 217, 315-329.

Bengtson, S., Sallstedt, T., Belivanova, V., Whitehouse, M. (2017) Threedimensional preservation of cellular and subcellular structures suggest 1.6 billion-year-old crown-group red algae. PLoS Biology 15, e2000735.

Canfield, D.E., Zhang, S., Frank, A.B., Wang, X., Wang, H., Su, J., Ye, Y., Frei, R. (2018) Highly fractionated chromium isotopes in Mesoproterozoic-aged shales and atmospheric oxygen. Nature Communications 9, 1-11.

Diamond, C.W., Planavsky, N.J., Wang, C., Lyons, T.W. (2018) What the 1.4 Ga Xiamaling Formation can and cannot tell us about the mid-Proterozoic ocean. Geobiology 16, 219-236.

EricKson, B.E., Helz, G.R. (2000) Molybdenum(VI) speciation in sulfidic waters: Stability and lability of thiomolybdates. Geochimica et Cosmochimica Acta 64, 1149-1158.

Hutchings, A.M., Basu, A., Dickson, A.J., Turchyn, A.V. (2020) Molybdenum geochemistry in salt marsh pond sediments. Geochimica et Cosmochimica Acta 284, 75-91.

Kendall, B., DahL, T.W., Anbar, A.D. (2017) The stable isotope geochemistry of molybdenum. Reviews in Mineralogy and Geochemistry 82, 683-732.

Li, H., Su, W., Zhou, H., Xiang, Z., Tian, H., Yang, L., Huff, D.W., Ettensohn, R.F. (2014) The first precise age constraints on the Jixian System of the Meso- to Neoproterozoic Standard Section of China: SHRIMP zircon U-Pb dating of bentonites from the Wumishan and Tieling formations in the Jixian Section, North China Craton. Acta Petrologica Sinica 30, 2999-3012 (in Chinese with English abstract).

NÄgler, T.F., Anbar, A.D., Archer, C., Goldberg, T., Gordon, G.W., Greber, N.D., SieberT, C., Sohrin, Y., VAnce, D. (2014) Proposal for an international molybdenum isotope measurement standard and data representation. Geostandards and Geoanalytical Research 38, 149-151.

Neubert, N., NÄgler, T.F., BÖTtcher, M.E. (2008) Sulfidity controls molybdenum isotope fractionation into euxinic sediments: Evidence from the modern Black Sea. Geology 36, 775-778.

Planavsky, N.J., Reinhard, C.T., Isson, T.T., Ozaki, K., Crockford, P.W. (2020) Large mass-independent oxygen isotope fractionations in midProterozoic sediments: Evidence for a low-oxygen atmosphere? Astrobiology 20, 628-636.

Poulton, S.W., CANFELD, D.E. (2011) Ferruginous conditions: A dominant feature of the ocean through Earth's history. Elements 7, 107-112.

Shang, M., TANG, D., ShI, X., Zhou, L., Zhou, X., Song, H., JiAng, G. (2019) A pulse of oxygen increase in the early Mesoproterozoic ocean at ca. 1.57-1.56 Ga. Earth and Planetary Science Letters 527, 115797.

Siebert, C., Nägler, T.F., von Blanckenburg, F., KRamers, J.D. (2003) Molybdenum isotope records as a potential new proxy for paleoceanography. Earth and Planetary Science Letters 211, 159-171.

Swanner, E.D., Lambrecht, N., Wittkop, C., Harding, C., Katsev, S., Torgeson, J, Poulton, S.W. (2020) The biogeochemistry of ferruginous lakes and past ferruginous oceans. Earth-Science Reviews 211, 103430.

Tian, H. et al. (2015) Zircon LA-MC-ICPMS U-Pb dating of tuff from mesoproterozoic Gaoyuzhuang Formation in Jixian County of North China and its geological significance. Acta Geoscientica Sinica 36, 647-658 (in Chinese with English abstract).

Wang, X., Zhang, S., Wang, H., Bierrum, C.J., Hammarlund, E.U., HaXen, E.R Su, J., Wang, Y., CANField, D.E. (2017) Oxygen, climate and the chemical evolution of a 1400 million year old tropical marine setting. American Journal of Science 317, 861-900.

Zhang, K., Zhu, X., WoOd, R.A., SHI, Y., GaO, Z., Poulton, S.W. (2018) Oxygenation of the Mesoproterozoic ocean and the evolution of complex eukaryotes. Nature Geoscience 11, 345-350.

ZHANG, S. et al. (2016) Sufficient oxygen for animal respiration 1,400 million years ago. Proceedings of the National Academy of Sciences 113, 1731-1736.

Zhu, S., Zhu, M., Knoll, A.H., Yin, Z., ZhaO, F., Sun, S., Qu, Y., SHI, M., Liu, H. (2016) Decimetre-scale multicellular eukaryotes from the 1.56-billionyear-old Gaoyuzhuang Formation in North China. Nature Communications 7, 11500 